\title{
ZÁLEŽÍ NA VZDIALENOSTI? (ZA NÁKUPOM NA TRNAVSKÝ RÍNEK)
}

\section{Petra Hencelová*, František Križan*, Kristína Bilková**, Michala Sládeková Madajová**}

\footnotetext{
* Univerzita Komenského v Bratislave, Prírodovedecká fakulta, Katedra regionálnej geografie a rozvoja regiónov, Ilkovičova 6,84215 Bratislava, hencelova10@uniba.sk, frantisek.krizan@uniba.sk

** Geografický ústav SAV, Štefánikova 49, 81473 Bratislava, kristina.bilkova@savba.sk, geogmada@savba.sk
}

\begin{abstract}
Does the distance matter? (Shopping at Trnava market - Trnavský rínek)
The aim of the paper is to evaluate the consumer's behaviour at the occasional market in Trnava - Trnavský rínek. The paper focuses on the characterization of a typical market visitor as well as on delimitation of the market's trade area. Data was obtained from a questionnaire survey $(\mathrm{n}=335)$. A one-dimensional ANOVA model, chisquare test and Mann-Whitney U test were used to test the hypotheses. Consumers come mainly from the cities and smaller countryside parts within a distance of $60 \mathrm{~km}$. Based on the results of the hypothesis testing, it was confirmed that the time spent at Trnavský rínek depends on the trade areas from which the visitors come. There is no statistically significant difference between the amount of money spent at Trnavský rínek and the trade areas of the visitors' residence. The overall satisfaction with Trnavský rínek does not depend on the trade areas from which the visitors come. The knowledge obtained from this research leads to a more detailed understanding of the consumer's behaviour and can be used to plan alternative places of consumption.
\end{abstract}

Key words: occasional market, consumer behaviour, trade areas, Trnava market - Trnavský rínek, city of Trnava

\section{ÚVOD}

Príchod zahraničných maloobchodných ret’azcov a ich koncept vel'kometrážnych maloobchodných predajní bol po štyroch „chudobných“ dekádach nakupovania za totality pre väčšinu spotrebitel'ov viac než splneným snom (Spilková 2017, p. 231). Spotrebitelia na Slovensku a v ostatných postkomunistických krajinách začali preferovat' vel'kometrážne maloobchodné predajne pred tradičnými lokalitami nakupovania. Kým v nedávnej minulosti dominoval impulzívny štýl nakupovania v zmysle nákupu a následného rozhodovania a riešenia otázky „Čo s tým?“, v súčasnosti možno v nakupovaní pozorovat' trend označovaný ako orientácia na hodnotu a kvalitu. V ostatnom období je pre slovenských spotrebitel'ov pri rozhodovaní o nákupe dôležitejšia skôr kvalita tovaru ako jeho cena (GfK 2021). Ukazuje sa, že spotrebitelia stále viac preferujú čerstvé potraviny a sú ochotní za nimi denne dochádzat' (Kunc et al. 2013). Súčasní spotrebitelia sa čoraz viac orientujú na zdravé potraviny, zaujíma ich nielen pôvod produktov, ktoré konzumujú, ale aj kto a ako ich vyrába, kde sa pestujú alebo či sú šetrné k životnému prostrediu (Tong et al. 2012 a Spilková 2016). Ide o trend odklonu od globálneho k lokálnemu, od konzumerizmu k zodpovednej (udržatel'nej) spotrebe (Križan a Bilková 2019), čo vedie aj k rozvoju nových foriem maloobchodného predaja tzv. alternatívnych potravinových sietí (Spilková 2016). Rozvoj alternatívnych potravinových sietí súvisí aj so zmenou správania spotrebitel'ov, ked’že zmenenému správaniu spotrebitel'ov sa prispôsobuje maloobchod (maloobchodníci). 
Ako tvrdí Spilková (2012), výskumná agenda geografie maloobchodu a spotreby sa rozvinula okolo mnohých tém vrátane alternatívnych potravinových sietí. O farmárske trhy (alternatívne potravinové siete vo všeobecnosti) prejavujú v ostatnom desat'ročí značný záujem spotrebitelia aj vedci. Trhy možno považovat' aj za „katalyzátor“ rozvoja a posilňovania sociálnych väzieb, ako formu spoločenskej udalosti, ktoré sa v súčasnosti stali modelom mestskej obnovy, kultúrnym strediskom alebo ciel'om turistov (González 2020). Zepeda a Li (2006) zdôrazňujú lokálnu produkciu ako významný faktor fungovania trhov predstavujúcich lokálne potravinové iniciatívy. Koncept konania trhov a lokálneho predaja $\mathrm{v}$ tržniciach má v regiónoch Slovenska tradíciu (Žudel 1973 a Bitušíková 1997). V súčasnosti ide o oživenie predaja lokálnych potravín s ciel’om obnovy tradícií trhov najmä v centrách miest. Trhy a trhoviská sa udržali v mestách aj napriek rozmachu maloobchodných prevádzok, zvýšenému nárastu nákupných centier alebo online nakupovaniu.

Spilková (2016, pp. 57 - 58) diskutuje o zmenách správania spotrebitel’ov smerom $\mathrm{k}$ postmaterialistickým hodnotám $\mathrm{v}$ súlade $\mathrm{s}$ trendmi v západnej Európe. Vývoj správania spotrebitel'ov (v kontexte postkomunistickej krajiny) sa prejavuje dôrazom na individualitu, ekonomické aspekty a zdržanlivost'ou v prijímaní skôr „alternatívnych“ postojov. Výskum správania spotrebitel'ov na farmárskych trhoch, ktoré sú formou alternatívnych potravinových sietí, zostáva v úzadí slovenskej geografie. Aj preto je zámerom autorov zhodnotit' správanie spotrebitel'ov (návštevníkov) na trhu (Trnavský rínek). Ciel'om príspevku je hl'adanie odpovedí na nasledovné výskumné otázky:

1 - Odkial' prichádzajú návštevníci na Trnavský rínek? Úlohou je delimitovat' zóny nákupného spádu Trnavského rínku a charakterizovat' spotrebitel’ov na trhovisku.

2 - Aké je správanie návštevníkov na Trnavskom rínku? Úlohou je zhodnotit' správanie a percepcie spotrebitel'ov nakupujúcich na trhu vzhl'adom na lokality ich bydliska.

V tejto súvislosti sme si stanovili nasledujúce hypotézy:

1 - Čas strávený na Trnavskom rínku nezávisí od zóny nákupného spádu, z ktorej návštevník prichádza.

2 - Množstvo minutých financií na Trnavskom rínku nezávisí od zóny nákupného spádu, z ktorej návštevník prichádza.

3 - Účel návštevy Trnavského rínku nezávisí od zóny nákupného spádu, z ktorej návštevník prichádza.

4 - V celkovej spokojnosti s Trnavským rínkom neexistuje rozdiel vzhl'adom na zónu nákupného spádu, z ktorej návštevník prichádza.

\section{FARMÁRSKE TRHY}

Termín trh (trhovisko) je široko a nejednotne definovaný. Vo všeobecnosti, trhy majú tendenciu kombinovat' ponuku potravín a tovarov s umeleckými remeslami, pričom môžu na trhoch dominovat' aj maloobchodníci (Jones et al. 2007). Trhy lákajú spotrebitel'ov svojou jedinečnost'ou, širokým sortimentom produktov, kvalitou (potravín) a sociálnou atmosférou trhu (Szmigin et al. 2003). Na základe rôznych definícií možno pod termínom trh chápat' viacero formátov a inštitucionálnych usporiadaní, akými sú pojazdné trhy (ambulantný predaj), periodické, nefor- 
málne, formálne a pouličné trhy, komunálne trhy a pod. Z pohl'adu správcovstva trhov, Sweet (1961) rozlišuje komunálne, verejné a farmárske trhy. Spilková (2012) poznamenáva, že je potrebné rozlíšit' tradičné tržnice so zeleninou a ovocím, na ktorých sa predávajú potraviny aj z vel'koskladov, a farmárske trhy, kde farmári predávajú vlastnú produkciu. Všetko, čo sa nazýva farmársky trh, nemusí obsahovat' práve tento termín a iné termíny, akým je trhovisko, môžu mat' formu a funkciu farmárskeho trhu (Pyle 1971). Brown (2001) upozorňuje, že na skutočnom farmárskom trhu sú zastúpení niektorí predajcovia, ak nie všetci producenti, ktorí predávajú svoje vlastné produkty. Verejné trhy, komunálne trhy, farmárske stánky, pouličné stánky, výmeny ekologického spotrebného a potravinárskeho tovaru, blšie trhy sa môžu občas nazývat' farmárskymi trhmi. Zamieňanie termínov trhovisko a farmársky trh je časté, pričom termín trhovisko nie vždy vystihuje termín farmársky trh a vice versa.

Farmárske trhy sú všeobecne považované za najstaršiu a najbežnejšiu formu priameho predaja potravín. Tradičný potravinový ret'azec (producent - vel'koobchod - maloobchod - spotrebitel') je v prípade farmárskych trhov charakteristický znižovaním počtu aktérov $\mathrm{v}$ tomto ret’azci, $\mathrm{t}$. $\mathrm{j}$. približovaním sa producentov k spotrebitel'ovi (producent - spotrebitel'). Farmárske trhy sú chápané ako lokality nákupu čerstvých a kvalitných potravín s priatel'skou nákupnou atmosférou (Spilková 2016).

Farmárske trhy majú viacero pozitívnych dosahov na miestnu ekonomiku, akými sú zvýšenie počtu pracovných miest, diverzifikácia regionálneho pol’nohospodárstva, zvýšenie ziskovosti lokálnych pol'nohospodárov alebo prít’ažlivost' trhov pre turistov. Spilková et al. (2013) uvádzajú d’alšie benefity, ktoré trhy prinášajú: lokálne potraviny, lepšia kvalita potravín, vyšší potenciál sociálnej interakcie, priame vzdelávanie o postupoch výroby potravín. Trhy možno chápat' ako základňu predaja lokálnych produktov a miesto nákupnej atmosféry (Brown 2002). Podl’a výskumu Chena a Scotta (2014) alebo Oñederra-Aramendia et al. (2018) je dôležitým motívom návštevy farmárskych trhov popri nákupe potravín aj uspokojovanie sociálnych a emocionálnych potrieb nakupujúcich. Spotrebitelia považujú farmárske trhy za lokalitu sociálnej interakcie, kde sa delia o spoločné ideály, užívajú si atmosféru a zaujímajú sa o budovanie sociálnych vzt’ahov s farmármi, ako aj s inými spotrebitel'mi (Cassia et al. 2012). Sociálny aspekt návštevy farmárskych trhov zohráva dôležitú úlohu aj v prípade minutých financií. Podl’a Pilařa et al. (2019) spotrebitelia na farmárskych trhoch najviac míňajú na zábavu.

Otvorené trhy sa stali neoddelitel'nou súčast'ou postkomunistických ekonomík strednej a východnej Európy. Majú tendenciu špecializovat' sa aj na predmety dlhodobej spotreby (napr. odevy, obuv, spotrebiče, hračky a iné) a najčastejšie odzrkadl'ujú sezónne odchýlky v predávanom tovare (Sik a Wallace 1999). Spomedzi postkomunistických krajín našla téma farmárskych trhov a výskum správania spotrebitel'ov na trhoch najväčšiu odozvu v českej geografii (Spilková a Perlín 2013, Spilková et al. 2013, Syrovátková et al. 2015, Fendrychová a Jehlička 2018 a Hruška et al. 2020). Rozvoj alternatív vo forme farmárskych trhov je viditel'ným prvkom potravinovej štruktúry aj v Pol'sku či Mad'arsku a u spotrebitel'ov získavajú stále väčšiu obl’ubu (Balász 2012, Grzelak a Maciejczak 2013, Balász et al. 2016, Malak-Rawlikowska et al. 2019 a Goszczyński et al. 2019). Na Slovensku má výskum farmárskych trhov a ich návštevníkov iba marginálne postavenie (Kita a Kollár 2018, Kollár 2018 a Hencelová et al. 2020). 
Medzi spotrebitel'mi (zákazníkmi) rôznych maloobchodných formátov existujú významné rozdiely. Aj ked' demografické a sociálno-ekonomické charakteristiky spotrebitel'ov sú stále dôležitými črtami ich segmentácie, lokalita nákupu alebo alternatívne možnosti získavania potravín patria medzi najdôležitejšie rozlišujúce faktory, ktoré charakterizujú spotrebitel'ov (Spilková 2018). Vo všeobecnosti väčšinu spotrebitel'ov na trhoch tvoria ženy (Wolf et al. 2005 a Zepeda 2009). Ekonomické premenné, akými sú príjem a výdavky na potraviny, nemajú výrazný vplyv na ochotu a mieru nakupovania na trhoch (Kita a Kollár 2018), avšak postoje týkajúce sa dôležitosti ceny potravín na trhoch majú výrazný vplyv (Zepeda 2009).

\section{METÓDY A DÁTA}

Aplikované metódy možno rozdelit’ do troch skupín. Prvú skupinu tvoria metódy zberu dát. Primárne dáta boli zozbierané pomocou dotazníkového prieskumu (cf. Carey et al. 2011). Dotazníkový prieskum bol realizovaný so spotrebitel'mi (335 respondentov) na občasnom trhu Trnavský rínek v meste Trnava v októbri 2019. Išlo o nepravdepodobnostný zámerný výber respondentov (Rochovská et al. 2014), s ciel'om analyzovat' správanie a percepcie spotrebitel'ov starších ako 18 rokov. V tomto kontexte je potrebné dáta interpretovat'. Ked'že všetci respondenti boli návštevníkmi Trnavského rínku, v príspevku je termín respondent (spotrebitel') stotožňovaný s termínom návštevník. Realizovaný dotazník bol rozdelený do troch sekcií. Po úvodných (sociálno-demografických) otázkach (vek, pohlavie, vzdelanie, príjem domácnosti a pod.), nasledovala sekcia s otázkami o motivácii návštevy trhu, o spotrebitel'skom správaní, ako aj vyjadrenie názorov na organizáciu trhu a pod. Posledná sekcia bola zameraná na priestorový aspekt problematiky (spôsob a čas dochádzky na trh a pod.). Ďalším metodickým postupom zberu dát bolo pozorovanie na trhu spojené s fotodokumentáciou (cf. Spilková et al. 2013).

$\mathrm{Na}$ analýzu dát (druhá skupina metód) bola využitá deskriptívna a induktívna štatistika. Na testovanie hypotézy 1 bol použitý model jednorozmernej analýzy rozptylu ANOVA v programe SPSS. Analyzovanou otázkou 1 bolo: „Kol'ko času priemerne strávite na návšteve Trnavského rínku?" s otvorenými odpoved’ami. Použitie ANOVA predpokladá rovnost' rozptylov jednotlivých výberov (zist'ovanú prostredníctvom Levenovho testu), ktorý však nebol potvrdený v prípade hypotézy 2. Na skúmanie rozdielov medzi zónami nákupného spádu a množstvom minutých financií (otázka 2: „Kol’ko financií miniete na Trnavskom rínku?" s otvorenými odpoved’ami) sme preto použili vhodnú obdobu neparametrického testu pre tento prípad, a to Mann-Whitneyho U test (cf. Gaur a Gaur 2006). Na testovanie hypotézy 3 bol použitý chí-kvadrát test pre dve premenné (cf. Spilková et al. 2013). Analyzovaná otázka 3 „S akým ciel’om najčastejšie chodíte na toto trhovisko?“ umožňovala výber max. troch odpovedí z nasledujúcich možností: Len nákup potravín; Len tak obzerat' tovar; Nakupovanie pre potešenie; Stretnutie s priatel'mi; Zábava a rozptýlenie; Nákup spotrebného tovaru; Aktivity pre deti; Workshopy; Iné. Štatisticky významné rozdiely medzi spokojnost'ou návštevníkov a zónou nákupného spádu (hypotéza 4) boli testované opät' prostredníctvom Mann-Whitneyho U testu pre ordinálne škálovanú závislú premennú (Otázka 4: „Aká je vaša celková spokojnost' s Trnavským rínkom?" s možnost'ou hodnotenia na pät'stupňovej likertovej škále). Do skupiny metód analýzy dát patrí aj aplikovaná delimitácia zón nákupného spádu využitím geografických informačných systémov (cf. Križan et al. 2020). 
Interpretácia dát a ich vizualizácia zastupujú tretiu skupinu metód. Ide o kartografické znázornenie analyzovaného javu. Využité boli metóda figurálnych znakov, metóda líniových prvkov a kombinácia oboch techník.

\section{CHARAKTERISTIKA TRNAVSKÉHO RÍNKU}

Pravidelné týždenné trhy sa začali v Trnave konat' už začiatkom 11. storočia. V 12. storočí sa trh uskutočňoval pri Kostole sv. Mikuláša, na dnešnom Námestí sv. Mikuláša, na Jeruzalemskej a Kapitulskej ulici. História konania trhov bola ešte v polovici 20. storočia neoddelitel'nou súčast'ou mesta Trnava. Trh bol zvyčajne $\mathrm{v}$ sobotu a miesto konania sa v centre menilo. Okrem pol'nohospodárskych prebytkov, vína a potrieb do domácnosti sa na trhoch $\mathrm{v}$ minulosti predávalo aj oblečenie. V súčasnosti sa na území mesta Trnava nachádza iba jedno otvorené trhovisko mimo centrum mesta, kde sa organizuje príležitostný trh (sobota). Podl'a trhového poriadku úplného znenia VZN č. $246^{1}$ o podmienkach predaja výrobkov a poskytovania služieb na trhových miestach mesta Trnava slúži trhovisko iba na predaj ovocia, zeleniny a kvetov. Trhovisko dopĺn̆a maloobchodnú vybavenost' mesta Trnava (Trembošová et al. 2016).

Na tradíciu trhov v centre mesta Trnava nadväzuje Trnavský rínek - občasný trh organizovaný občianskym združením Bronco. Trnavský rínek je koncipovaný ako spoločenské a kultúrne podujatie s frekvenciou dvakrát do roka (v mesiacoch máj a október). Koncept priestorového usporiadania trhu pozostáva $\mathrm{z}$ viacerých častí: stánky s výrobkami, gastro zóna, oddychová zóna, zóna pre deti. Súčastou Trnavského rínku sú hudobné vystúpenia, literárne čítanie a tvorivé dielne pre deti. Organizátori Trnavského rínku, inšpirovaní Dobrým trhom v meste Bratislava, sa riadia piatimi základnými piliermi zásad pri výbere predajcov (lokálni producenti a výrobcovia, malopredajcovia, ekologické vyhotovenie výrobkov, originálny prístup a prezentácia aktivít lokálnych neziskových organizácií). Snahou organizátorov Trnavského rínku je vytvorit’ atmosféru mestského trhu (obr. 1).

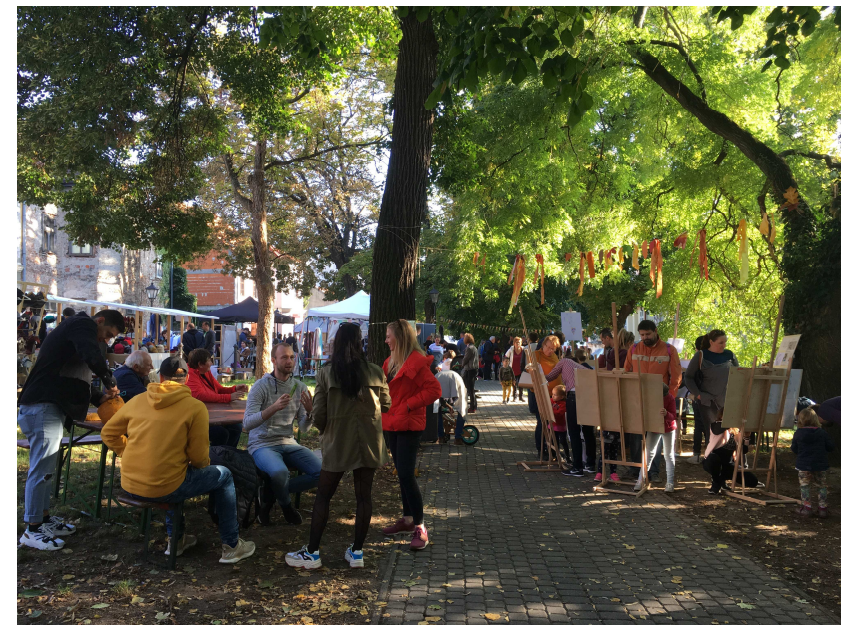

Obr. 1. Atmosféra na Trnavskom rínku

Autor: Petra Hencelová

\footnotetext{
${ }^{1}$ https://www.trnava.sk/sk/vseobecne-zavazne-nariadenie/246 [cit. 6.4.2020]
} 
Potraviny predávané na Trnavskom rínku možno označit’ ako lokálne (z kraja) a regionálne (slovenský pôvod), ked’že na trhu predávajú aj predajcovia a maloobchodníci z celého Slovenska. Potravinársku ponuku tvorí zelenina a ovocie, domáce koláče, limonády, káva a iné produkty domácej výroby (čerstvé cestoviny, med, mak, zaváraniny, paštéty, sirupy a iné). Ponuku Trnavského rínku dotvára aj predaj hotového jedla, bazár kníh, predaj hand-made a fair-trade produktov (oblečenie, mydlá, hračky, keramika, šperky, doplnky a iné).

Plošný parameter (predajná plocha $\mathrm{v}$ maloobchode na obyvatel'a) dosahuje v Trnave nadpriemerné hodnoty. Z doterajších výskumov vyplýva, že rozhodujúcim faktorom výberu lokality nákupu je pre Trnavčanov cena tovaru a lokalita predajne. Najviac preferovanými sú vel'koplošné predajne typu hypermarket a supermarket (Trembošová et al. 2016). Spotrebitel'ov v Trnave možno zaradit' do skupiny sporivý nákupný typ, ktorý minimalizuje výdaje, nakupuje racionálne a málo využíva auto. Trnavskí spotrebitelia sa pri nakupovaní zatial' správajú tradične, avšak populácia už smeruje k modernému nákupnému správaniu (Trembošová et al. 2018).

\section{NÁVŠTEVNÍCI TRNAVSKÉHO RÍNKU}

Kto sú, odkial' a prečo prichádzajú návštevníci na Trnavský rínek? Z uskutočneného výskumu vyplýva, že priemerný vek návštevníka na Trnavskom rínku je 33,2 roka, z čoho možno usudzovat' zvýšený záujem mladšej generácie spotrebitel'ov (generácia Y). Takmer polovica respondentov má najvyššie dosiahnuté vzdelanie vysokoškolské (49 \%) a viac ako polovica respondentov je zamestnaných (53\%). Až $52 \%$ respondentov žije v domácnosti s manželom/manželkou a det'mi. Viac ako štvrtina respondentov $(27 \%)$ má čistý mesačný príjem domácnosti viac ako $2000 €$ (tab. 1).

Polovica návštevníkov Trnavského rínku sú obyvatelia mesta Trnava (51\%). $\mathrm{Z}$ mimotrnavských návštevníkov prevažujú návštevníci z vidieka $(57 \%)$, celkovo však podiel mestských návštevníkov tvorí $71 \%$ (tab. 1). Priemerná vzdialenost' medzi bydliskom návštevníkov a Trnavským rínkom je $23,8 \mathrm{~km}$. Do $5 \mathrm{~km}$ od Trnavského rínku žije polovica návštevníkov, do $15 \mathrm{~km}$ je to $65 \%$ návštevníkov a do $30 \mathrm{~km}$ až $79 \%$ návštevníkov. Z okresu Trnava pochádza 67 \% návštevníkov (obr. 2).

Z analyzovaných dát vyplýva, že Trnavský rínek nemožno považovat' len za lokálny trh $\mathrm{z}$ hl'adiska bydliska návštevníkov. Tak to vnímajú aj návštevníci: „Trnavský rínek je udalost', ktorá pritiahne l'udí aj z d’alekého okolia.“" (muž, 28ročný). Jeho nákupný spád siaha za hranice mesta, okresu a kraja. Preto sme v d’alšej časti analýzy pristúpili k delimitácii zón nákupných spádov pre Trnavský rínek. Zóna nákupného spádu je ,územie, z ktorého je možné prilákat' zákazníkov a generovat' tržby“ (Baviera-Puig et al. 2012, p. 1 413), ide o priestor, z ktorého prichádzajú potenciálni spotrebitelia (Huff 1964). Zóna nákupného spádu má svoju priestorovú mierku, ktorá môže byt' rozličná, a zákazníci sú v ňom nerovnomerne rozmiestnení. V literatúre je preto zaužívaná klasifikácia zón nákupného spádu do troch skupín (Applebaum 1966) - primárna, sekundárna a terciárna. Primárna zóna nákupného spádu je územie, v ktorom žije 60 - 70 \% návštevníkov. V prípade Trnavského rínku sme aplikovali podiel 65 \% všetkých návštevníkov. V priestore ide o vzdialenost' $15 \mathrm{~km}$ od trhu (obr. 3). Hoci pre termín lokálny nie je všeobecne pri- 
jatá definícia jeho priestorového vymedzenia (Selfa a Qazi 2005), v prípade tejto štúdie a z empirických poznatkov možno za lokálnych spotrebitel'ov považovat' tých, ktorí majú bydlisko v primárnej zóne nákupného spádu. Sekundárna zóna nákupného spádu nadväzuje na primárnu. Je pre ňu charakteristický druhý najvyšší podiel návštevníkov $(15-25 \%)$. V prípade Trnavského rínku sme aplikovali podiel $20 \%$ všetkých návštevníkov, čo predstavuje hranicu vo vzdialenosti 15,1 60,0 km od lokality nákupu. Terciárna (okrajová) zóna nákupného spádu zahrnuje ostatných návštevníkov žijúcich vo vzdialenosti viac ako $60 \mathrm{~km}$. Do terciárnej zóny nákupného spádu patrí zvyšné územie Slovenska. Najvzdialenejšie bydlisko návštevníka Trnavského rínku bolo mesto Humenné. Avšak možno predpokladat', že návšteva Trnavského rínku nebola primárnym ciel'om cesty do Trnavy.

Tab. 1. Základné charakteristiky respondentov ( $\mathrm{n}=335$, priemerný vek 33,2 roka)

\begin{tabular}{|c|c|c|c|}
\hline \multicolumn{3}{|c|}{ Charakteristiky respondentov } & Podiel respondentov (v \%) \\
\hline \multicolumn{4}{|c|}{ Pohlavie } \\
\hline Muž & & & 43,3 \\
\hline Žena & & & 56,7 \\
\hline \multicolumn{4}{|c|}{ Najvyššie dosiahnuté vzdelanie } \\
\hline Vysokoškolské & & & 48,9 \\
\hline Stredoškolské s matu & & & 22,5 \\
\hline Stredoškolské bez ma & y, odborné & & 27,5 \\
\hline Základné & & & 1,1 \\
\hline \multicolumn{4}{|c|}{ Status } \\
\hline Zamestnaný & & & 53,2 \\
\hline Samostatne zárobkov & iný & & 10,1 \\
\hline Študent & & & 23,9 \\
\hline Dôchodca & & & 2,7 \\
\hline Materská dovolenka & & & 6,4 \\
\hline Nezamestnaný & & & 3,7 \\
\hline \multicolumn{4}{|c|}{ Prijem domácnosti } \\
\hline Do $500 €$ & & & 5,8 \\
\hline 501 až $1000 €$ & & & 19,2 \\
\hline 1001 až $1500 €$ & & & 26,4 \\
\hline 1501 až $2000 €$ & & & 21,7 \\
\hline Viac ako $2000 €$ & & & 26,9 \\
\hline \multicolumn{4}{|c|}{ Bydlisko } \\
\hline & Spolu (\%) & Mesto (\%) & Vidiek $(\%)$ \\
\hline Návštevníci & 100 & 71 & 29 \\
\hline z toho mimotrnavskí & 49 & 43 & 57 \\
\hline z toho trnavskí & 51 & 100 & 0 \\
\hline
\end{tabular}

Farmárske trhy už nie sú len lokalitami nákupu zdravých, čerstvých a ekologických potravín, ale sú aj lokalitou stretávania s priatel'mi alebo trávenia vol'ného času (Pilař et al. 2019). To sa potvrdilo aj v prípade Trnavského rínku, kde návštevníci prichádzajú prevažne za zábavou, rozptýlením a stretnutiami s priatel'mi a za významné pozitívum považujú priatel'skú atmosféru trhu. 

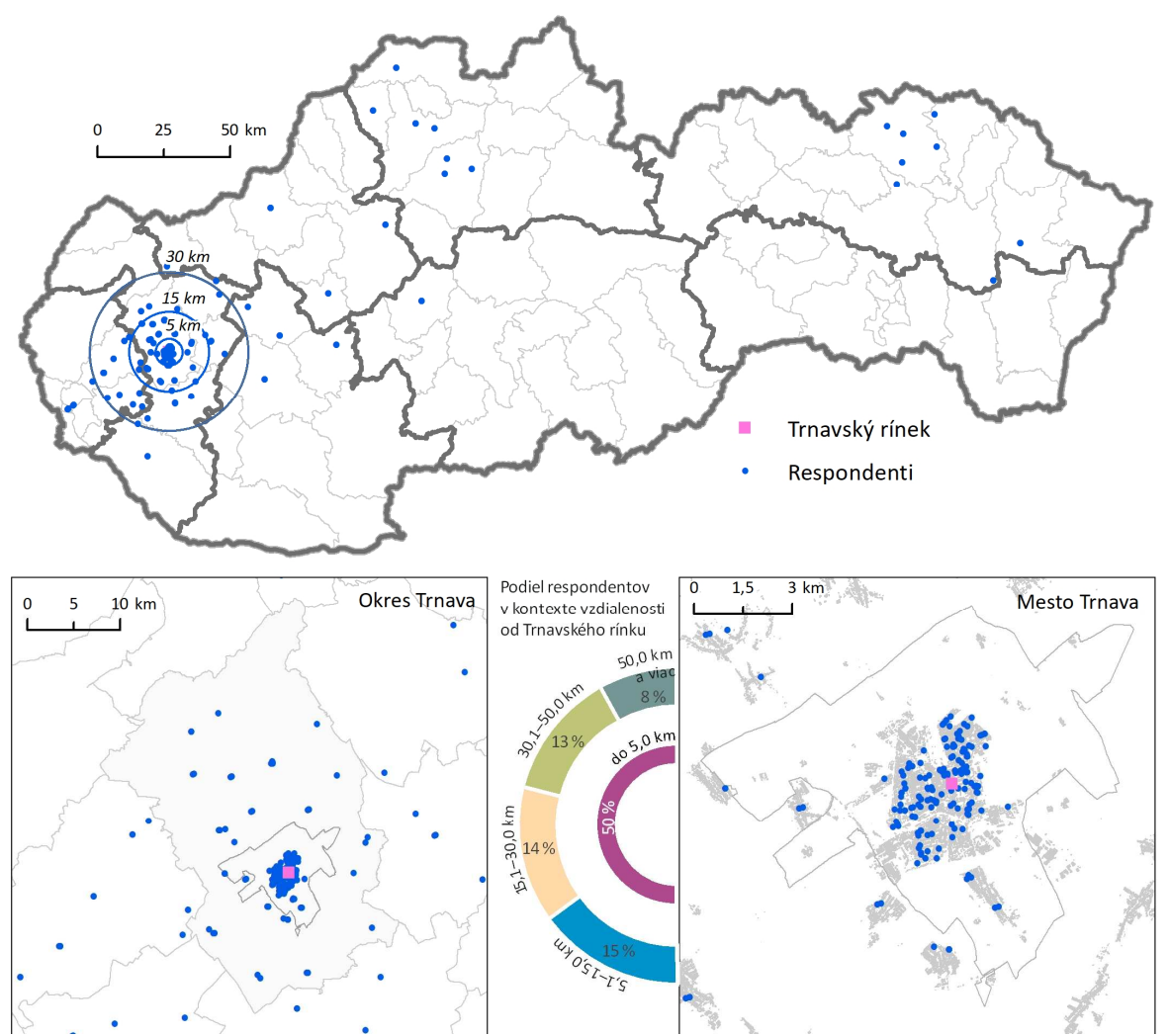

Obr. 2. Lokality bydliska návštevníkov Trnavského rínku

Vysvetlivky: okrem Trnavy nie je lokalita viazaná na súpisné číslo bydliska.

Zdroj: vlastný výskum.

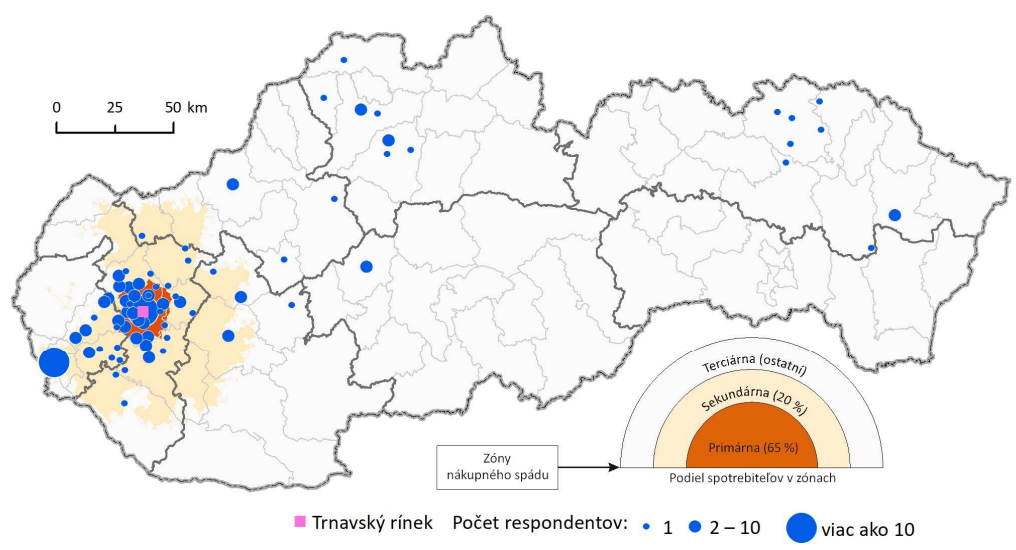

Obr. 3. Delimitácia zón nákupného spádu Trnavského rínku Zdroj: vlastný výskum. 
Návštevníci z primárnej zóny nákupného spádu prichádzajú na trh najmä s ciel'om stretnutí s priatel'mi $(22 \%)$ a za zábavou a rozptýlením (19\%). Iba $10 \%$ návštevníkov príde na Trnavský rínek „len na nákup potravín“ (obr. 4). Až 27 \% návštevníkov zo sekundárnej a terciárnej zóny nákupného spádu prichádza na trh predovšetkým za zábavou a rozptýlením. Možno tvrdit', že návštevníci zo vzdialenejších lokalít prichádzajú na trh viac za pôžitkom z trhu a nakupovaním pre potešenie $(22 \%) \mathrm{v}$ porovnaní $\mathrm{s}$ návštevníkmi $\mathrm{z}$ primárnej zóny nákupného spádu $(16 \%)$.

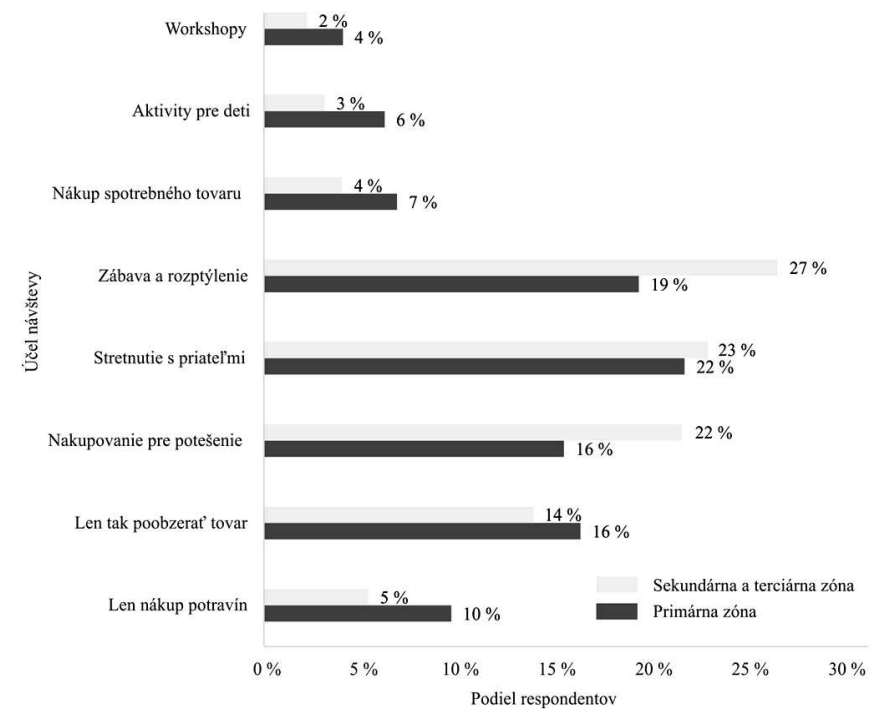

Obr. 4. Účel návštevy spotrebitel’ov podl’a zón nákupného spádu Zdroj: vlastný výskum.

\section{VÝSLEDKY TESTOVANIA HYPOTÉZ}

V kontexte stanovených ciel'ov sme sa v d’alšej časti analýzy sústredili na zhodnotenie správania spotrebitel'ov z primárnej zóny nákupného spádu v porovnaní so správaním ostatných spotrebitel'ov (zo sekundárnej a terciárnej zóny nákupného spádu). Návštevníci z primárnej zóny nákupného spádu strávia na Trnavskom rínku v priemere 115 minút a utratia 36 eur, pričom návštevníci zo sekundárnej a terciárnej zóny nákupného spádu strávia na rínku v priemere 154 minút a utratia o 7 eur viac (43 eur). Testovaním hypotéz sa preukázalo, že zatial' čo hypotézu 1 zamietame na hladine významnosti $0,1 \%(\mathrm{p}=0,000)$, hypotézu 2 zamietnut' nemôžeme $(\mathrm{p}=0,125)$. Znamená to, že s pravdepodobnost'ou väčšou ako 99,9\% čas strávený na Trnavskom rínku závisí od zóny nákupného spádu, z ktorého návštevník prichádza, ale medzi množstvom minutých financií na Trnavskom rínku a zónou nákupného spádu, z ktorej návštevník prichádza, neexistuje štatisticky významný vzt’ah. Ako možné vysvetlenie sa ponúka väčšia vzdialenost' od lokality bydliska, čo znamená, že ak sa niekto rozhodne cestovat' d'alej na trh, snaží sa podl'a možnosti o čo najväčšie zúročenie tam stráveného času. Rentabilita nákupu pritom pravdepodobne nezohráva podstatnú úlohu. Testovaním hypotézy 3 sa preukázalo, že účel návštevy Trnavského rínku závisí od zóny nákupného spádu, z ktorej návštevník prichádza $(\mathrm{p}=0,018)$. 
Návštevníci Trnavského rínku vnímajú trhoviská prevažne pozitívne $(55,1 \%)$ alebo skôr pozitívne $(38,2$ \%). Ojedinele sa vyskytli aj negatívne postoje k trhoviskám $(0,6 \%)$, resp. skôr negatívne $(4,0 \%)$. Nevedelo sa rozhodnút' $2,1 \%$ respondentov. Pri zhodnotení konkrétnych pozitívnych a negatívnych percepcií sú pozitívne postoje návštevníkov zamerané najmä na ponuku jedál na trhovisku: ,vegánske jedlo, bezlepkové potraviny a jedlo“ (muž, 31-ročný), ,vel’a dobrého jedla, rôznorodost' a originalita jedla“ (muž, 32-ročný). Návštevníci pozitívne hodnotili aj prostredie a predávaný tovar: „,príjemná atmosféra, lokálne výrobky“ (žena, 21ročná) alebo „miesto, kde stretnem priatel’ov, krásne veci, nové chute“ (žena, 27 ročná) či ,šetrnost' k životnému prostrediu, podpora lokálnych výrobcov, príjemná atmosféra, skvelé podujatie" (žena, 40-ročná). Pozitívny postoj k trhovisku je príznačný pre návštevníkov zo všetkých zón nákupných spádov. Negatívne percepcie návštevníkov možno rozdelit' do dvoch skupín. Prvá skupina negatívnych percepcií (návštevníkov prevažne z primárnej zóny) je zameraná na priestor: „malý priestor, vel'a l'udí a málo priestoru na sedenie“ (žena, 27-ročná) alebo „preplnenost' lokality v posledných rokoch“ (muž, 23-ročný). Druhá skupina negatívnych percepcií je zameraná na cenu a organizáciu rínku: „vysoké ceny potravín, vel’a l’udí“ (žena, 22-ročná), „dlhé čakanie v radoch“ (žena, 38-ročná), „chýbajúce WC“ (žena, 34-ročná) alebo „plastové príbory“ (muž, 26-ročný) a prevažuje u návštevníkov zo sekundárnej a terciárnej zóny nákupného spádu.

Analýza percepcií návštevníkov v súvislosti s celkovou spokojnost’ou s Trnavským rínkom vychádzala z likertovej škály 1 až 5 , kde 1 znamená vel'mi spokojný (maximálna spokojnost') a 5 nespokojný (minimálna spokojnost'). Pri hl'adaní odpovedí na otázku 2 sme testovali aj nulovú hypotézu 4, že rozdiely v priemeroch hodnotenia celkovej spokojnosti s Trnavským rínkom medzi jednotlivými odpoved’ami účastníkov z rôznych zón nákupného spádu nie sú významné, čo sa aj potvrdilo $(\mathrm{p}=0,675)$. Celková spokojnost' $\mathrm{s}$ Trnavským rínkom teda nezávisí od zóny nákupného spádu, z ktorého návštevník prichádza.

\section{ZÁVER}

Farmárske trhy sú všeobecne považované za istý (alternatívny) spôsob zlepšenia lokálneho prístupu k potravinám. V ostatnom období možno na Slovensku pozorovat' zvýšený záujem o realizáciu trhov v mestskom prostredí, nadväzujúc na tradície a históriu konania trhov v centrách miest v minulosti. Je potrebné poznamenat', že na Slovensku nie je prijatá definícia farmárskeho trhu a neexistuje ani farmársky kódex (ako je to napríklad v Česku). Trnavský rínek nie je klasickým pravidelne organizovaným farmárskym trhom, ale občasným trhom s prvkami farmárskeho trhu. Na túto skutočnost' je potrebné pri interpretácii výsledkov a diskusii prihliadat'.

V príspevku sme hl'adali odpovede na dve výskumné otázky. Prvá bola zameraná na delimitáciu zóny nákupného spádu Trnavského rínku. V tejto súvislosti sme pristúpili k identifikácii priestoru, z ktorého prichádzajú návštevníci na Trnavský rínek. Priemerná vzdialenost' medzi bydliskom návštevníkov a Trnavským rínkom je 23,8 km. Do $5 \mathrm{~km}$ od Trnavského rínku žije polovica návštevníkov, do $30 \mathrm{~km}$ až 79 \% návštevníkov. Z okresu Trnava pochádza 67 \% návštevníkov. Zo vzdialenosti nad $50 \mathrm{~km}$ dochádza 7,5 \% návštevníkov. Diskusiu k týmto výsledkom nechávame otvorenú, ked'že tematické štúdie zo Slovenska a okolitých krajín nám nie sú známe. Obdobné výsledky však prináša štúdia z Nórska, kde väčšina návštevníkov žije 
do $15 \mathrm{~km}$ od farmárskeho trhu a priemerná vzdialenost' dochádzky na trh je $14 \mathrm{~km}$. Nad 50 km žije iba 10 \% návštevníkov (Åsebø et al. 2007).

$\mathrm{Na}$ základe dát o lokalite bydliska návštevníkov sme pomocou geografických informačných systémov delimitovali primárnu, sekundárnu a terciárnu zónu nákupného spádu Trnavského rínku. Je však potrebné poznamenat', že trh môže byt' pre potenciálneho návštevníka neprístupný napriek tomu, že sa nachádza v tesnej blízkosti lokality jeho bydliska. Príkladom je konanie trhu v čase, ked' ho spotrebitel' nemôže navštívit'. Preto štúdie, ktoré takéto obmedzenia ignorujú, vedú k prehnaným záverom o význame dostupnosti. Navyše, väčšina spotrebitel'ov pri návšteve trhu kombinuje svoju cestu realizáciou viacerých aktivít (Mack a Tong 2015), čo bolo pozorované aj v prípade návštevníkov Trnavského rínku.

Druhá výskumná otázka bola zameraná na zhodnotenie správania návštevníkov nakupujúcich na Trnavskom rínku. Typickým návštevníkom na Trnavskom rínku je zamestnaný vysokoškolsky vzdelaný spotrebitel' zaradený do generácie Y žijúci v manželstve s det'mi. Z výsledkov výskumu vyplýva, že čas strávený na Trnavskom rínku závisí od zóny nákupného spádu, z ktorej návštevník prichádza. Návštevníci z primárnej zóny nákupného spádu strávia priemerne o 39 min. menej času na trhu ako ostatní návštevníci. Ked’že ide o trh s množstvom sprievodných spoločenských udalostí, možno predpokladat', že priemerný čas strávený na Trnavskom rínku dosahuje vyššie hodnoty ako na typickom pravidelne organizovanom farmárskom trhu (cf. George et al. 2016). Závislost' od zóny nákupného spádu sa však neprejavila $\mathrm{v}$ prípade analýzy množstva minutých financií. Priemerné výdavky na občasnom Trnavskom rínku sú vyššie ako v prípade pravidelného farmárskeho trhu, kde sa výdavky odlišujú aj v závislosti od sezóny, pričom v zime sú vyššie ako v lete (Zepeda a Carroll 2018). V prípadovej štúdii z regiónu Dunajská Streda autori (Kita a Kollár 2018) konštatujú, že farmárske trhy ponúkajú okrem produktov aj inú pridanú hodnotu vo forme zážitkov, čo má pozitívny vplyv na preferenciu nákupov na farmárskych trhoch. Zároveň bolo potvrdené, že spotrebitelia s rôznymi príjmami majú rovnakú vôl'u nakupovat' na farmárskych trhoch.

Alternatívne potravinové siete sa v ostatnom období stali oblúbenými lokalitami spotreby vo všetkých vekových a sociálnych skupinách spotrebitel'ov (Spilková 2018). Návštevníci Trnavského rínku vo všeobecnosti vnímajú trhoviská pozitívne. Avšak nepreukázala sa závislost' medzi celkovou spokojnost’ou s Trnavským rínkom a zónou nákupného spádu, z ktorej návštevník prichádza.

Výsledky nášho výskumu naznačujú, že väčšina návštevníkov príde na Trnavský rínek s ciel'om zábavy a rozptýlenia, čo je pre akademickú obec zaujímavé poznanie pri výskume aktuálnych trendov v správaní spotrebitel'ov na (farmárskych) trhoch. Z pohl'adu praxe (organizátorov trhu) ide taktiež o zaujímavý poznatok. Organizátori môžu rozvíjat' Trnavský rínek nielen ako lokalitu nákupu, ale aj lokalitu sociálnych interakcií v zmysle kultúrneho programu, zábavných aktivít, workshopov, t. j. nesústredit' pozornost' iba na výber predajcov potravín, resp. tovarov. Na docielenie vyššej návštevnosti trhu „mimotrnavskými“ návštevníkmi môžu organizátori zvolit' vhodný marketing pre potenciálnych návštevníkov, ked’že účel návštevy Trnavského rínku závisí od zóny nákupného spádu, z ktorej návštevník prichádza. Trnavský rínek považujeme za vhodný objekt výskumu správania spotrebitel'ov a výsledky výskumu môžu byt' využitel'né pri organizácii obdobných podujatí zameraných na podporu a rozvoj lokálneho potravinového systému. Poznanie správania návštevníkov na trhu môže byt' zúročené pri formulácii chýbajúceho kódexu farmárskych trhov na Slovensku. 
Aktuálna situácia šírenia vírusu SARS-CoV-2 a obmedzenia prijaté vládami po celom svete istotne ovplyvnia nákupné správanie spotrebitel'ov aj na trhoviskách. Ako sa zmení správanie spotrebitel'ov, ich percepcie a preferencie $\mathrm{v}$ priestore a čase po potlačení pandémie - to je námet na budúci výskum.

Táto práca bola podporovaná Agentúrou na podporu výskumu a vývoja na základe zmluvy č. APVV-16-0232 a zmluvy č. APVV-20-0302 a projektom VEGA 2/0113/19.

\section{LITERATÚRA}

APPLEBAUM, W. (1966). Methods for determining store trading areas, market penetration and potential sales. Journal of Marketing Research, 3, 127-141. DOI: https:// doi.org/10.1177/002224376600300202.

ÅSEBØ, K., JERVELL, A. M., LIEBLEIN, G., SVENNERUD, M., FRANCIS, C. (2007). Farmer and consumer attitudes at farmers markets in Norway. Journal of Sustainable Agriculture, 30, 67-93. DOI: https://doi.org/10.1300/J064v30n04_06.

BALAZS, B. (2012). Local food system development in Hungary. International Journal of Sociology of Agriculture \& Food, 19, 403-421. DOI: https://doi.org/10.48416/ ijsaf.v19i3.212.

BALÁZS, B., PATAKI, G., LAZÁNYI, O. (2016). Prospects for the future: Community supported agriculture in Hungary. Futures, 83, 100-111. DOI: https://doi.org/10.1016/ j.futures.2016.03.005.

BAVIERA-PUIG, A., BUITRAGO-VERA, J., MAS-VERDÚ, F. (2012). Trade areas and knowledge-intensive services: The case of a technology centre. Management Decision, 50, 1412-1424. DOI: https://doi.org/10.1108/00251741211262006.

BITUŚÍKOVÁ, A. (1997). Mesto ako regionálne centrum. Etnologické rozpravy, 4, 63-70.

BROWN, A. (2001). Counting farmers markets. Geographical Review, 91, 655-674. DOI: https://doi.org/10.1111/j.1931-0846.2001.tb00246.x.

BROWN, A. (2002). Farmers' market research 1940 - 2000: An inventory and review. American Journal of Alternative Agriculture, 17, 167-176.

CAREY, L., BELL, P., DUFF, A., SHERIDAN, M., SHIELDS, M. (2011). Farmers' market consumers: A Scottish perspective. International Journal of Consumer Studies, 35, 300-306. DOI: https://doi.org/10.1111/j.1470-6431.2010.00940.x.

CASSIA, F., UGOLINI, M., BONFANTI, A., CAPPELLARI, C. (2012). The perceptions of Italian farmers' market shoppers and strategic directions for customer-companyterritory interaction (CCTI). Procedia - Social and Behavioural Sciences, 58, 1008 1017. DOI: https://doi.org/10.1016/j.sbspro.2012.09.1081.

FENDRYCHOVÁ, L., JEHLIČKA, P. (2018). Revealing the hidden geography of alternative food networks: The travelling concept of farmers' markets. Geoforum, 95, 1-10. DOI: https://doi.org/10.1016/j.geoforum.2018.06.012.

GAUR, A. S., GAUR, S. S. (2006). Statistical methods for practice and research: A guide to data analysis using SPSS. London (Sage).

GEORGE, D. R., MANGLANI, M., MINNEHAN, K., CHACON, A., GUNDERSEN, A., DELLASEGA, C., KRASCHNEWSKI, J. L. (2016). Examining feasibility of mentoring families at a farmers' market and community garden. American Journal of Health Education, 47, 94-98. DOI: https://doi.org/10.1080/19325037.2015.1133340.

GfK (2021). GfK Consumer Panel Slovakia, Why2Buy survey. Bratislava (GfK).

GONZÁLEZ, S. (2020). Contested marketplaces: Retail spaces at the global urban margins. Progress in Human Geography, 44, 877-897. DOI: https://doi.org/10.1177/ 0309132519859444.

GOSZCZYŃSKI, W., ŚPIEWAK, R., BILEWICZ, A., WRÓBLEWSKI, M. (2019). Between imitation and embeddedness: Three types of Polish alternative food networks. Sustainability, 11, 7059. DOI: https://doi.org/10.3390/su11247059. 
GRZELAK, P., MACIEJCZAK, M. (2013). Comparison between the United States and Poland of consumers' perceptions of organic products. Studies in Agricultural Economics, 115, 47-56. DOI: https://doi.org/10.7896/j.1302.

HENCELOVÁ, P., KRIŽAN, F., BILKOVÁ, K. (2020). Farmárske trhy v Bratislave: Ilúzia vs. realita. In Križan, F., et al. eds. Kde nakupujeme, čo nakupujeme a prečo nakupujeme: lokality maloobchodu a spotreby a správanie spotrebitel'ov. Bratislava (Univerzita Komenského v Bratislave), pp. 189-201.

HRUŠKA, V., KONEČNÝ, O., SMUTNÁ, Z., DUŽÍ, B. (2020). Evolution of alternative food networks in an old industrial region of Czechia. Erdkunde, 74, 143-159. DOI: https://doi.org/10.3112/erdkunde.2020.02.04.

HUFF, D. L. (1964). Defining and estimating a trading area. Journal of Marketing, 28(3), 34-38. DOI: https://doi.org/10.1177/002224296402800307.

CHEN, W., SCOTT, S. (2014). Shoppers' perceived embeddedness and its impact on purchasing behaviour at an organic farmers' market. Appetite, 83, 57-62. DOI: https:// doi.org/10.1016/j.appet.2014.08.010.

JONES, P., HILLIER, D., COMFORT, D. (2007). Changing times and changing places for market halls and covered markets. International Journal of Retail \& Distribution Management, 35, 200-209. DOI: https://doi.org/10.1108/09590550710735059.

KITA, P., KOLLÁR, P. (2018). Food purchasing behaviour of consumers on farmers' markets: A case study from the region Dunajská Streda. In: Pech, M., Matějčková, M., eds. Innovations, Enterprises, Regions and Management. The 11th International Conference INPROFORUM 2017. Ceské Budějovice (University of South Bohemia in České Budějovice), pp. 229-235.

KOLLÁR, P. (2018). Threats and opportunities for rural retail in the conditions of Dunajska Streda district. Ekonomické rozhl'ady, 47, 250-261.

KRIŽAN, F., BILKOVÁ, K. (2019). Geografia spotreby: úvod do problematiky. Bratislava (Univerzita Komenského).

KRIŽAN, F., BARLÍK, P., BILKOVÁ, K., HENCELOVÁ, P. (2020). Delimitácia intraurbánnej nákupnej zóny na základe mobilných dát: prípadová štúdia Avion Shopping Parku (Bratislava). Studia commercialia Bratislavensia, 44, 140-149.

KUNC, J., MARYÁŠ, J., TONEV, P., FRANTÁL, B., SIWEK, T., HALÁS, M., KLAPKA, P., SZCZYRBA, Z., ZUSKÁČCVÁ, V. (2013). Časoprostorové modely nákupního chováni české populace. Brno (Masarykova univerzita). DOI: https://doi.org/ 10.5817/ CZ.MUNI.M210-6020-2013.

MACK, J., TONG, D. (2015). Characterizing the spatial and temporal patterns of farmers' market visits. Applied Geography, 63, 43-54. DOI: https://doi.org/10.1016/j.apgeog. 2015.06.005.

MALAK-RAWLIKOWSKA, A., MAJEWSKI, E., WĄS, A., BORGEN, S. O., CSILLAG, P., DONATI, M., FREEMAN, R., HOÀNG, V., LECOEUR, J-L., MANCINI, M. C., NGUYEN, A., SAÏDI, M., TOCCO, B., TÖRÖK, Á., VENEZIANI, M., VITTERSØ, G., WAVRESKY, P. (2019). Measuring the economic, environmental, and social sustainability of short food supply chains. Sustainability, 11, 4004. DOI: https:// doi.org/10.3390/su11154004.

OÑEDERRA-ARAMENDI, A., BEGIRISTAIN-ZUBILLAGA, M., MALAGÓN-ZALDUA, E. (2018). Who is feeding embeddedness in farmers' markets? A cluster study of farmers' markets in Gipuzkoa. Journal of Rural Studies, 61, 22-33. DOI: https:// doi.org/10.1016/j.jrurstud.2018.05.008.

PILAŘ, L., STANISLAVSKÁ, L. K., MOULIS, P., KVASNIČKA, R., ROJÍK, S., TICHÁ, I. (2019). Who spends the most money at farmers' markets?. A gricultural Economics, 65, 491-498. DOI: https://doi.org/10.17221/69/2019-AGRICECON.

PYLE, J. (1971). Farmers' markets in the United States: Functional anachronisms. Geographical Review, 61, 167-197. DOI: https://doi.org/10.2307/213994.

ROCHOVSKÁ, A., KÁČ́EROVÁ, M., ONDOS̆, S. (2014). Výskumné metódy v humánnej geografii a ich aplikácie. Bratislava (Univerzita Komenského). 
SELFA, T., QAZI, J. (2005). Place, taste, or face-to-face? Understanding producerconsumer networks in "local" food systems in Washington State. Agriculture and Human Values, 22, 451-464. DOI: https://doi.org/10.1007/s10460-005-3401-0.

SIK, E., WALLACE, C. (1999). The development of open-air markets in East-Central Europe. International Journal of Urban and Regional Research, 23, 697-714. DOI: https://doi.org/10.1111/1468-2427.00223.

SPILKOVÁ, J. (2012). Geografie maloobchodu a spotřeby: věda o nakupování. Praha (Karolinum).

SPILKOVÁ, J. (2016). Alternativní potravinové sítě: Česká cesta. Praha (Karolinum).

SPILKOVÁ, J. (2017). „Co je malé, to je hezké ... Co je větší, to je hezčí?“: hledání cest pro alternativu v českém maloobchodu. In Križan, F., Bilková, K., Barlík, P., eds. Maloobchod a špecifiká časovo-priestorového správania spotrebitelov. Bratislava (Univerzita Komenského), pp. 231-239.

SPILKOVÁ, J. (2018). "Tell me where you shop, and I will tell you who you are": Czech shopper profiles according to traditional, large-scale and alternative retail options. $\mathrm{Mo}$ ravian Geographical Reports, 26, 186-198. DOI: https://doi.org/10.2478/mgr-20180015.

SPILKOVÁ, J., FENDRYCHOVÁ, L., SYROVÁTKOVÁ, M. (2013). Farmers’ markets in Prague: A new challenge within the urban shoppingscape. Agriculture and Human Values, 30, 179-191. DOI: https://doi.org/10.1007/s10460-012-9395-5.

SPILKOVÁ, J., PERLÍN, R. (2013). Farmers' markets in Czechia: Risks and possibilities. Journal of Rural Studies, 32, 220-229. DOI: https://doi.org/10.1016/j.jrurstud. 2013.07.001.

SYROVÁTKOVÁ, M., HRABÁK, J., SPILKOVÁ, J. (2015). Farmers' markets' locavore challenge: The potential of local food production for newly emerged farmers' markets in Czechia. Renewable Agriculture and Food Systems, 30, 305-317. DOI: https:// doi.org/10.1017/S1742170514000064.

SWEET, M. L. (1961). History of municipal markets. Journal of Housing, 18, 237-247.

SZMIGIN, I., MADDOCK, S., CARRIGAN, M. (2003). Conceptualising community consumption. British Food Journal, 105, 542-550. DOI: https://doi.org/10.1108/ 00070700310497291.

TONG, D., FEN, F., MACK, J. (2012). Locating farmers' markets with an incorporation of spatio-temporal variation. Socio-Economic Planning Sciences, 46, 149-156. DOI: https://doi.org/10.1016/j.seps.2011.07.002.

TREMBOŠOVA,, M., DUBCOVÁ, A., CIVÁŇ, M. (2016). Geografické aspekty maloobchodnej siete mesta Trnava a nákupné správanie jej obyvatel'stva. Nitra (Univerzita Konštantína Filozofa v Nitre).

TREMBOŠOVÁ, M., MÁČAJOVÁ, M., MOČKO, M. (2018). Modely nákupného správania obyvatel'ov mestských častí mesta Trnava. Geografické informácie, 22, 299-314. DOI: https://doi.org/10.17846/GI.2018.22.2.299-314.

WOLF, M. M., SPITTLER, A., AHERN, J. (2005). A profile of farmers' market consumers and the perceived advantages of produce sold at farmers' markets. Journal of Food Distribution Research, 36, 192-201. DOI: https://doi.org/10.22004/ag.econ.26768.

ZEPEDA, L. (2009). Which little piggy goes to market? Characteristics of US farmers' market shoppers. International Journal of Consumer Studies, 33, 250-257. DOI: https:// doi.org/10.1111/j.1470-6431.2009.00771.x.

ZEPEDA, L., CARROLL, K. A. (2018). Who shops at a mature farmers' market? Choices, 33(3), $1-7$.

ZEPEDA, L., LI, J. (2006). Who buys local food? Journal of Food Distribution Research, 37(3), 1-11. DOI: https://doi.org/10.22004/ag.econ.7064.

ŽUDEL, J. (1973). Trhové sféry na Slovensku v roku 1720. Geografický časopis, 25, 299-312. 


\section{Petra He n c e lo vá, František Križan, Kristína Bi lková, Michala Slád eková Madajová}

\section{DOES THE DISTANCE MATTER? (SHOPPING AT TRNAVA MARKET - TRNAVSKÝ RÍNEK)}

The aim of the paper is to evaluate the consumer's behaviour at the occasional market Trnavský rínek in the city of Trnava (Western Slovakia). The intention is to find answers to the following research questions: 1: Where do the visitors of Trnavský rínek come from? The task is to delimit the market's trade areas and to characterize consumers at the market. 2: What is this event's visitors' behaviour? The task is to assess the consumer's behaviour and perceptions with regards to their place of residence.

The average distance between the visitors' residence and Trnavský rínek is $23.8 \mathrm{~km}$. Half of the visitors live within $5 \mathrm{~km}$ from Trnavský rínek, almost 79\% of visitors within 30 $\mathrm{km}$. Two-thirds of visitors come from the Trnava district and $7.5 \%$ of visitors come from a distance of more than $50 \mathrm{~km}$. The primary trade area was delimited as the zone within a distance of $15 \mathrm{~km}$ from the marketplace, from which $65 \%$ of visitors come. The secondary trade area was delimited at a distance of $15.1 \mathrm{~km}$ to $60.0 \mathrm{~km}$ from the market, which represents $20 \%$ of all visitors. The remaining area represents the tertiary trade area.

Consumer behaviour was analysed on a sample of 335 visitors. In the paper, the following hypotheses were tested: (1): The time spent on Trnavský rínek does not depend on the trade area from which the visitor comes. (2): The amount of money spent on Trnavský rínek does not depend on the trade area from which the visitor comes. (3): The purpose of a visit to Trnavský rínek does not depend on the trade area from which the visitor comes. (4): There is no difference in the overall satisfaction with Trnavský rínek no matter where the visitor's residence is.

A typical visitor of Trnavský rínek is an employed, married, university-educated consumer with children who belongs to generation Y. The visitors from the primary trade area were considered to be local, their behaviour was compared with other visitors' behaviour in the context of established hypotheses concerning the time and amount of money spent and the purpose of their visit and the overall satisfaction with Trnavský rínek. The results of the research show that the time spent at Trnavský rínek depends on the trade area from which the visitor comes (hypothesis 1). In the case of the amount money spent at Trnavský rínek, the correspondence with the trade area was not confirmed (hypothesis 2). It was confirmed that the purpose of visiting Trnavský rínek depends on the trade area from which the visitor comes (hypothesis 3). In general, the visitors of Trnavský rínek perceive marketplaces positively. The overall satisfaction with Trnavský rínek does not depend on the trade area from which the visitor comes (hypothesis 4).

The limiting factor of this study is the sample of respondents and the analysis of only one marketplace. For more general conclusions, further research into alternative food networks focused on the economic, social and environmental aspects of shopping behaviour is needed. 
